\title{
KIMBERLITE-CONTROLLING ZONES IN THE CRUST AND UPPERMOST MANTLE OF THE WEST YAKUTIA: THEIR COMPOSITION AND EVOLUTION.
}

A.F. Safronov; V.D. Suvorov; A.I. Zaitsev; N.I. Nenashev and I.P. Shcherbakova. Institute of Geological Sciences, Lenin avenue 39, Yakutsk, 677007, USSR.

Seismic studies of the uppermost mantle in the southern part of the Yakutian kimberlite province (YKP). Western Yakutia, have established a narrow, linear zone of anomalously high velocities (up to $8.5-9.0 \mathrm{~km} / \mathrm{s}$ ) along the Moho. All known kimberlite fields of the southern YKP are located within this zone. Rb - Sr and $\mathrm{K}$ - Ar age determinations of kimberlite rocks crustal and upper mantle rocks xenoliths and samples of the buried basement from within the zone gave the following age intervals: 1000 1290, $600-900,340-390,210-230 \mathrm{Ma}$. Ages of crustal and upper mantle xenoliths and buried basement rocks fall in all the four intervals, whereas those of kimberlite rocks correspond to the last two younger intervals. The spatial confinement of the dated samples to the above mentioned zone permits us to consider it as a kimberlite-controlling-zone (KCZ).

Along the Moho, the $\mathrm{KCZ}$ is expressed by the predominance of eclogites over peridotites. Geophysical characteristics of the crust suggest it is saturated with small peridotite bodies.

The formation of the KCZ began no later than $1200 \mathrm{Ma}$ ago and proceeded in several episodes corresponding to the above age intervals. Each of the episodes could be consisted with an epoch of kimberlite magmatism.

It appears that $\mathrm{KCZ}$ in the crust and uppermost mantle as well as exposed kimberlites indicate the beginning of destruction of the continental lithosphere 
process can proceed as follows: 1) Initiation of $\mathrm{KCZ}$ and eruption of kimberlites. 2)Further development of $\mathrm{KCZ}$ is expressed by pre-rift surface upwarping and eruption of kimberlites and picrites. 3) The onset of continental rifting and manifestation of rift magmatism.

The confinement of some kimberlite provinces to passive continental margins is an indirect evidence for such a scenario of $\mathrm{KCZ}$ evolution. 